\title{
PEMBERDAYAAN MASYARAKAT BERBASIS PARIWISATA
}

\author{
Sochimin \\ sochimin@iainpurwokerto.ac.id \\ Prodi Ekonomi Syariah \\ Fakultas Ekonomi dan Bisnis Islam IAIN Purwokerto
}

\begin{abstract}
Tourism in Indonesia has worldwide because of its diverse tourism potential and extensive natural beauty. However, this does not make the community around the tourist sites enjoy many benefits from the development of aspects of tourism in their area because it requires the public to understand the tourism potential needed in their area, so that the government has the duty and responsibility to empower the community so that the community can use the tourism potential. The concept of community empowerment is based on concepts that represent the community not only as objects, but also as subjects. In the object position, the goal is the community which still needs to be given guidance or direction so that management can continue to develop and achieve goals, while the subject position is the community is the determinant in the development itself, the community is a very important aid in the development planning that has been carried out. Tourism is one of the new industries that is able to increase economic growth quickly in terms of employment opportunities, incomes, living standards and in terms of activating other production sectors in tourist recipient countries. Therefore, the development of locally based tourism does not directly involve the community to actively participate in developing the potential that exists in their area so that they can improve their welfare.
\end{abstract}

\section{A. Pendahuluan}

Negara Indonesia per 17 Juli 2017, memiliki 16.056 pulau sebagaimana dilaporkan kepada PBB pada konferensi ke-11 sidang UNCSGN oleh Kementrian Kelautan dan Perikanan (KKP) Indonesia. ${ }^{1}$ Pulau-pulau ini tentunya sarat dengan berbagai budaya dan

1 Ambari, Dikukuhkan di New York, Jumlah Pulau Indonesia Kini Sebanyak 16.056 dalam Mongabay, Situs Berita Lingkungan, Jakarta, 18 Agustus 2017. Diakses pada 06 Januari 2018. 
ciri khasnya masing-masing. Setiap pulau memiliki kekayaan sumber daya alam (SDA) yang melimpah, baik yang berupa perairan seperti laut, dan danau ataupun yang berupa daratan seperti pegunungan yang hijau. Dengan adanya kekayaan budaya dan sember daya alam (SDA) yang dimiliki oleh bangsa kita, seharusnya pemerintah dan masyarakat Indonesia bisa memanfaatkan hal tersebut untuk bisa maju dan meningkatkan kesejahteraan hidup mereka. Sayangnya, masyarakat belum bisa memanfaatkan kekayaan alam yang telah tersedia di daerah mereka.

Menurut data yang dilansir Badan Pusat Statistik (BPS), bahwa jumlah penduduk miskin di Indonesia per September 2016 mencapai angka 27,76 juta orang atau $10,70 \% .^{2}$ Angka ini cukup fantastik bagi negara Indonesia yang memiliki kekayaan alam dan budaya yang melimpah. Tingkat keberhasilan atau kegagalan pembangunan suatu negara dapat diukur berdasarkan perubahan angka kemiskinannya. Semakin berkurangnya angka kemiskinan, berarti negara tersebut sudah bisa dikatakan berhasil dalam pembangunan di negaranya. Oleh karena itu, kemiskinan menjadi salah satu hal yang harus diselesaikan dalam pembangunan negara.

Kemiskinan merupakan keadaan dimana seseorang tidak mampu untuk memenuhi kebutuhannya, dengan kata lain yang terjadi pada masyarakat miskin adalah ketidakseimbangan antara kebutuhan dengan upaya pemenuhan kebutuhan tersebut sehingga menyebabkan kekurangan dalam berbagai aspek kehidupan dan menurunnya kualitas hidup mereka.

Pada jalannya laju pembangunan suatu negara, salah satu faktor yang penting adalah faktor kualitas sumber daya manusia (SDM). Kualitas SDM yang rendah akan membuat masyarakat tidak mampu melihat dan mengatasi masalah yang mereka jalani, sebab pada umumnya, masyarakat miskin memiliki keterbelakangan secara ekonomi dilihat dari rendahnya produktivitas tenaga kerja.

Menurut Adisasmita, ada beberapa penyebab rendahnya produktivitas tenaga kerja masyarakat, di antaranya kondisi kesehatan yang rendah, tingkat pendidikan yang rendah, pelatihan yang terbatas, hambatan terhadap mobilitas pekerjaan, rendahnya kinerja/prestasi

2 Sumber http://setkab.go.id/bps-per-september-2016-jumlah-penduduk-miskin-indonesia bekurang-025-juta/ (diakses pada 1 November 2017) 
kerja. ${ }^{3}$ Atas hal tersebut, diperlukan pengembangan sumber daya manusia (SDM) untuk meningkatkan kualitas yang mereka miliki.

Pengembangan adalah suatu kegiatan yang terkondisi sebagai upaya untuk melakukan perubahan terencana kepada masyarakat. ${ }^{4}$ Pengembangan sumber daya manusia juga dapat diartikan sebagai suatu proses peningkatan kualitas atau kemampuan manusia dalam rangka mencapai suatu tujuan pembangunan bangsa. ${ }^{5}$ Proses peningkatan ini terdiri dari planning, education and training, dan management. Hasil dari pengembangan sumber daya manusia (SDM) ini dapat berupa barang ataupun uang.

Salah satu cara yang bisa digunakan untuk meningkatkan kualitas sumber daya manusia (SDM) adalah dengan cara manusia atau masyarakat harus ikut serta berpartisipasi dalam membangun daerah dan negara yang mereka tinggali. Strategi ini, biasa disebut dengan pemberdayaan pada masyarakat. Jadi, pemberdayaan masyarakat merupakan suatu usaha yang dilakukan untuk mengembangkan dan memberdayakan kondisi masyarakat secara aktif dan continue berdasarkan prinsip-prinsip keadilan sosial. ${ }^{6}$

Program pemberdayaan masyarakat dilaksanakan dengan pendekatan bottom up, dimana pada pelaksanaan kegiatan di lapangan dilakukan atas inisiatif dan aspirasi dari masyarakat, mulai dari kegiataan perencanaan, pelaksanaan sampai dengan pengawasan pelaksanaan pembangunan. ${ }^{7}$ Masyarakat adalah aktor utama atau pelaku penting yang harus selalu aktif dalam pelaksanaan. Keberhasilan atau kegagalan dari pelaksanaan juga ditentukan oleh masyarakat yang melaksanakan program tersebut.

Untuk mencapai tujuan dan keberhasilan dari kegiatan pemberdayaan masyarakat ini, setiap kegiatan yang dilakukan dalam pemberdayaan masyarakat harus dilandasi dengan strategi kerja atau dengan langkah-langkah yang tepat. Keberhasilan dari kegiatan pemberdayaan masyarakat ini dapat dilihat dari kemampuan

${ }^{3}$ Rahardjo Adisasmita, Dasar-Dasar Ekonomi Wilayah (Yogyakarta: Graha Ilmu, 2005), hlm. 203

${ }^{4}$ Kurnadi Shahab, Sosiologi Pedesaan, (Yogyakarta: Ar-Ruzz Media, 2013), hlm. 93

5 Soekidjo Notoatmodjo, Pengembangan Sumber Daya Manusia, (Jakarta: PT Rineka Cipta, 1998), hlm. 2-3

${ }^{6}$ Zubaedi, Pengembangan Masyarakat: Wacana dan Praktik, (Jakarta: Kencana, 2013), hlm. 4

${ }^{7}$ Rr. Suhartini, A. Halim, dkk, Model-Model Pemberdayaan Masyarakat, (Yogyakarta: PT LKiS Pelangi Aksara, 2005), hlm. 11-12 
masyarakat sebagai pelaksana, baik dari kemampuan ekonomi, kemampuan mengakses manfaat kesejahteraan, dan kemampuan kultural serta politis. ${ }^{8}$

Pemberdayaan merupakan suatu proses untuk meningkatkan kemampuan masyarakat. Oleh karena itu, kegiatan pemberdayaan ini harus diarahkan agar dapat merubah kehidupan mereka menjadi lebih baik. Perencanaan dalam kegiatan pemberdayaan ini harus bisa mengusahakan mereka untuk mempunyai kesempatan mengakses sumber-sumber ekonomi. ${ }^{9}$

Salah satu sektor yang bisa dimanfaatkan untuk mendukung kegiatan pemberdayaan masyarakat dan juga memanfaatkan sumberdaya lokal adalah mengembangkan sektor pariwisata. Kekayaan alam dan keberagaman budaya yang dimiliki oleh setiap daerah di Indonesia menyimpan banyak potensi sekaligus peluang usaha untuk membangun sektor pariwisata.

Selain itu, sektor pariwisata di Indonesia juga telah mendunia karena potensi pariwisatanya yang beraneka ragam, seperti keindahan pantai Indonesia, pegunungan yang hijau, dan juga peninggalanpeninggalan sejarah yang unik seperti candi-candi yang cukup banyak di Indonesia. Menurut data Badan Pusat Statistik (BPS) jumlah wisatawan mancanegara yang berkunjung ke Indonesia selama tahun 2016 mencapai 11,52 juta orang, naik 10,69\% dibandingkan dengan jumlah wisatawan mancanegara pada tahun $2015 .{ }^{10}$ Keadaan tersebut, tentu juga mendukung kegiatan pemberdayaan masyarakat melalui pariwisata di Indonesia.

Kepariwisataan merupakan salah satu komoditi yang mampu menghasilkan devisa yang cukup besar bagi negara, sehingga pemerintah pusat harus bisa mendukung pembiayaan pembangunan daerah agar bisa mengoptimalkan potensi pariwisata yang ada di setiap daerah di Indonesia. Adanya UU No 32 Tahun 2004 tentang Pemerintah Daerah dan UU No 33 Tahun 2004 tentang perimbang Keuangan Pusat dan Daerah, memberikan hak kepada pemerintah daerah untuk memanfaatkan dan mengembangkan sumber daya alam (SDA) dan budaya-budaya yang dimiliki oleh setiap daerah di

${ }^{8}$ Totok Mardikanto, Pemberdayaan Masyarakat: Dalam Perspektif Kebijakan Publik, (Bandung: Penerbit Alfabeta, 2012), hlm. 291

${ }^{9}$ Sunyoto Usman, Pembangunan dan Pemberdayaan Masyarakat, (Yogyakarta: Pustaka Pelajar, 2012), hlm. 31

${ }^{10}$ Sumber artikel http://googleweblight.com/ diakses pada Senin, 6 November 2017 
Indonesia agar dapat memberikan output yang optimal sehingga dapat meningkatkan kondisi perekonomian di daerahnya yang selanjutnya juga mendorong proses pembangunan negara. ${ }^{11}$

Pada proses perkembangan kepariwisataan, istilah umum yang kerap muncul adalah sustainable tourism atau wisata berkelanjutan. Istilah ini wisata berkelanjutan ini dapat dipandang sebagai suatu langkah untuk mengelola semua sumber daya yang secara sosial dan ekonomi dapat dipenuhi dengan memelihara integritas budaya, prosesproses ekologi yang mendasar, keragaman hayati, dan unsur-unsur pendukung kehidupan lainnya. ${ }^{12}$ Dengan demikian, pemberdayaan masyarakat dengan pengembangan istilah sustainaible tourism dapat diarahkan guna meningkatkan kesejahteraan masyarakat.

Selanjutnya, selain adanya UU yang mendukung setiap daerah untuk mengoptimalkan potensi sumber daya alam (SDA) yang tersedia, di sisi lain juga telah terjadi pergeseran minat wisatawan dari produk wisata konvensional beralih ke produk wisata yang lebih menghargai lingkungan, alam, budaya, serta atraksi-atraksi secara spesial. ${ }^{13}$ Keindahan alam yang ada dan intensitas interaksi wisatawan dengan masyarakat lokal bisa membuat wisatawan merasa nyaman. Adanya pergeseran minat wisatawan ini seharusnya bisa dimanfaatkan oleh masyarakat dan pemerintah daerah agar mengembangkan potensi di setiap daerah yang mereka tinggali.

Partisipasi masyarakat dalam mengelola dan mengembangkan potensi pariwisata di daerah mereka sangatlah penting, karena selain mereka akan mendapatkan pengetahuan tentang kepariwisataan, mereka juga bisa mendapat peluang untuk berwirausaha. Beberapa usaha yang bisa dijalankan beriringan dengan pengembangan pariwisata di daerah adalah kuliner, pertunjukkan seni atau budaya khas daerah, dan homestay atau resort.

Menurut Spillane, secara umum pariwisata dikembangkan sebagai suatu industri. Maksudnya adalah tujuan dari dikembangkannya sektor pariwisata adalah untuk menghasilkan atau

11 Sjafrizal, Perencanaan Pembangunan Daerah Dalam Era Otonomi, (Depok: RajaGrafindo Persada, 2016), hlm. 13

12 Dias Satria, Strategi Pengembangan Ekowisata Berbasis Ekonomi Lokal dalam Rangka Program Pengentasan Kemiskinan Di Wilayah Kabupaten Malang, Journal Of Indonesian Applied Economics, Vol. 3 No. 1 Mei 2009, 37- 47.

13 Dewi Winarni Susyanti, Potensi Desa Melalui Pariwisata Pedesaan, Jurnal (Jakarta: Politeknik Negeri Jakarta, 2014), hlm. 65 
meningkatkan devisa negara dan juga meningkatkan kesejahteraan masyarakat. Seperti yang telah diketahui sektor pariwisata merupakan salah satu sektor yang menghasilkan devisa negara yang cukup besar. ${ }^{14}$

Selain untuk menambah devisa negara dan meningkatkan kesejahteraan masyarakat, pemberdayaan masyarakat berbasis pariwisata juga mempunyai tujuan untuk membentuk masyarakat atau individu yang mandiri dalam segala hal, karena dalam pemberdayaan masyarakat, setiap individu harus berperan aktif dalam pembangunan potensi pariwisata di daerahnya.

Konsep pemberdayaan masyarakat berbasis pariwisata merupakan suatu konsep yang menegaskan bahwa posisi masyarakat bukan lagi hanya sebagai objek, tetapi juga subjek. ${ }^{15}$ Pada posisi objek, maksudnya adalah masyarakat masih perlu diberikan bimbingan atau arahan agar pengelolaan bisa terus berkembang dan bisa mencapai tujuan, sedangkan pada posisi subjek yaitu masyarakat adalah penentu dalam pembangunan itu sendiri, masyarakat adalah pelaku yang sangat penting dalam menentukan keberhasilan dari pembangunan yang sedang dilakukan.

Ada banyak potensi yang akan diperoleh dari sektor pariwisata, karena pariwisata dapat meningkatkan kesejahteraan masyarakat dengan beberapa karakteristiknya seperti kunjungan wisatawan yang ingin menikmati panorama yang ada sehingga dapat membuka peluang bagi penduduk lokal untuk memasarkan kuliner atau produk-produk khas yang ada di daerah mereka.

\section{B. Pemberdayaan}

Istilah "pemberdayaan" merupakan terjemahan dari istilah asing empowerment, yang berarti penguatan. ${ }^{16}$ Secara teknis istilah pemberdayaan dapat disamakan atau diserupakan dengan pengembangan, yang lebih tepatnya pengembangan sumber daya

${ }^{14}$ Anggiar Rizki F, dkk, Peran Serta Masyarakat Desa Dalam Inisiasi Pengembangan Wisata Alam Desa Wringinanom Keamatan Poncokusumo Kabupaten Malang, Jurnal, (Malang: Unversitas Brawijaya, 2016), hlm. 29

15 Iwan Nugroho, Ekowisata dan Pembangunan Berkelanjutan, (Yogyakarta: Pustaka Pelajar, 2011), hlm. 88

${ }^{16}$ Nanih Machendrawaty dan Agus Ahmad Safe'i, Pengembangan Masyarakat Islam, (Bandung: Rosdakarya, 2001) hlm. 41. 
manusia. Ini berarti masyarakat diberdayakan untuk melihat dan memilih sesuatu yang bermanfaat bagi dirinya. ${ }^{17}$

Pemberdayaan juga diartikan sebagai bentuk perluasan aset dan kemampuan masyarakat miskin dalam menegosiasikan, mempengaruhi, mengontrol, dan mengendalikan tanggung jawab lembaga-lembaga yang mempengaruhi kehidupannya, ${ }^{18}$ maka terkait dengan hal ini, pengertian pembangunan apapun yang diberikan terhadapnya, selalu merujuk pada upaya perbaikan, terutama perbaikan pada mutu hidup manusia, baik secara fisik, mental, ekonomi maupun sosial budayanya.

Mengacu pada konsep-konsep diatas, maka tujuan pemberdayaan meliputi beragam upaya perbaikan. Perbaikan tersebut di antaranya: ${ }^{19}$

1. Perbaikan Kelembagaan

Dengan perbaikan kegiatan/tindakan yang dilakukan, diharapkan akan memperbaiki kelembagaan termasuk pengembangan jejaring kemitraan - usaha.

2. Perbaikan Usaha

Meliputi perbaikan pada ranah pendidikan, perbaikan aksesibilitas, kegiatan, dan juga perbaikan lain yang diharapkan dapat memperbaiki bisnis yang dilakukan.

3. Perbaikan Pendapatan

Dengan perbaikan bisnis yang dilakukan, diharapkan akan dapat memperbaiki pendapatan yang diperolehnya, termasuk pendapatan keluarga dan masyarakatnya.

4. Perbaikan Lingkungan

Perbaikan pendapatan diharapkan dapat memperbaiki lingkungan karena kerusakan lingkungan seringkali disebabkan oleh kemiskinan atau pendapatan yang terbatas.

5. Perbaikan Kehidupan

Tingkat pendapatan dan keadaan lingkungan yang membaik, diharapkan dapat memperbaiki keadaan kehidupan setiap keluarga dan masyarakat.

6. Perbaikan Masyarakat

17 Ibid., hlm. 42.

${ }^{18}$ Zubaedi, Pengembangan Masyarakat Wacana \& Praktik, (Jakarta: Kencana Prenada Media Group, 2013) hlm. 72-73.

${ }^{19}$ Aprillia Theresia, dkk., Pembangunan Berbasis Masyarakat (Bandung: Alfabeta, 2014) hlm. 114-115. 
Keadaan kehidupan yang lebih baik, yang didukung oleh lingkungan yang lebih baik, diharapkan akan terwujud kehidupan masyarakat yang lebih baik pula. Sehingga, menurut Totok pemberdayaan masyarakat di sini dapat berarti upaya untuk meningkatkan harkat dan martabat lapisan masyarakat dari kondisi tidak mampu, serta melepaskan diri dari perangkap kemiskinan dan keterbelakangan ekonomi. ${ }^{20}$ Dengan kata lain, sebagai upaya membangun kemandirian rakyat di bidang ekonomi.

Pemberdayaan di bidang ekonomi merupakan upaya untuk membangun daya (masyarakat) dengan mendorong, memotivasi, dan membangkitkan kesadaran akan potensi ekonomi yang dimilikinya serta berupaya untuk mengembangkannya. Keberdayaan masyarakat adalah unsur dasar yang memungkinkan suatu masyarakat bertahan, dalam pengertian yang dinamis, yaitu mengembangkan diri dan mencapai kemajuan.

Masyarakat yang telah diberdayakan secara penuh potensinya akan meningkat bukan hanya ekonominya, tetapi juga harkat, martabat, rasa percaya diri, dan harga dirinya. Atas hal demikian, pemberdayaan ekonomi masyarakat dapat dilihat dari tiga $\mathrm{sisi}^{21} \mathrm{di}$ antaranya adalah:

1. Menciptakan suasana atau iklim yang memungkinkan potensi masyarakat berkembang. Titik tolak pemikirannya adalah pengenalan bahwa setiap manusia, dan setiap masyarakat, memiliki potensi yang dapat dikembangkan. Tidak ada masyarakat yang sama sekali tanpa daya.

2. Memperkuat potensi ekonomi yang dimiliki oleh masyarakat. Untuk memperkuat potensi ekonomi masyarakat upaya yang sangat pokok adalah peningkatan taraf pendidikan, derajat kesehatan, serta terbukanya kesempatan untuk memanfaatkan peluang-peluang ekonomi.

3. Mengembangkan ekonomi masyarakat juga mengandung arti melindungi rakyat dan mencegah terjadinya persaingan yang tidak seimbang serta mencegah eksploitasi golongan ekonomi yang kuat atas yang lemah. Upaya melindungi rakyat tersebut tetap dalam

20 Totok Mardikanto dan Poerwoko Soebianto, Pemberdayaan Masyarakat dalam Perspektif Kebijakan Publik (Bandung: Alfabeta, 2012), hlm. 39.

21 Nur Mahmudi Isma'il, "Strategi Pemberdayaan Umat dan Pencetakan SDM Unggul", www.library.walisongo.ac.id/digilib., diakses pada 04 Agustus 2014 pukul 11.25 WIB. 
rangka proses pemberdayaan dan pengembangan prakarsanya. $^{22}$ Melalui langkah-langkah yang nyata harus diupayakan agar pertumbuhan ekonomi masyarakat berlangsung secara cepat.

Sebagaimana telah disebutkan sebelumnya dalam konsep kepariwisataan, pemberdayaan masyarakat perlu diarahkan dan diperhatikan baik oleh pemerintah setempat atau pemerintah pusat, agar sesuai dengan asal mula pembangunan pariwisata karena apabila belum selaras akan menjadi kendala. Selain itu, pemikiran masyarakat dalam memandang wisatawan juga harus diubah yang tadinya wistawan hanya sebagai pendatang menjadi masyarakat berfikir bahwa wisatawan adalah sebagai peluang usaha dan aset kehidupan.

Berikut beberapa lingkup kegiatan pemberdayaan masyarakat antara lain:

1. Bina Manusia

Pengembangan bina manusia merupakan upaya pertama dan utama yang harus diperhatikan dalam setiap upaya pemberdayaan masyarakat. Hal ini, dilandasi oleh pemahaman bahwa tujuan pembangunan adalah untuk perbaikan mutu hidup atau kesejahteraan manusia.

2. Bina Usaha

Bina usaha yang diupayakan melalui pemberdayaa masyarakat akan mencakup banyak hal seperti:

a. Peningkatan pengetahuan teknis, utamanya untuk meningkatkan produktivitas, perbaikan mutu dan nilai tambah produk;

b. Perbaikan manajemen untuk meningkatkan efesiensi usaha;

c. Pengembangan jiwa kewirausahaan terkait dengan optimasi peluang bisnis yang berbasis dan didukung oleh keunggulan lokal;

d. Peningkatan aksesbilitas terhadap modal, pasar dan informasi;

e. Advokasi kebijakan yang berpihak kepada pengembangan ekonomi rakyat.

3. Bina Lingkungan

Pembangunan yang dilakukan Indonesia sejak awal 1970-an telah membawa dampak negatif sebagai perusak hutan terbesar, pencemaran lingkungan dari limbah industri/pertanian/rumah

${ }^{22}$ Mubyarto, Ekonomi Rakyat: Program IDT dan Demokrasi Ekonomi Indonesia, (Yogyakarta: Adtya Media, 1997), hlm. 37-38. 
tangga, serta perusak lahan dari kegiatan pertambangan. Menghadapi kegiatan tersebut, upaya pemberdayaan masyarakat terhadap kesadaran lingkungan sudah saatnya memperoleh perhatian yang serius.

4. Bina Kelembagaan

Pemberdayaan masyarakat melalui bina manusia, bina usaha dan bina lingkungan masyarakat perlu tersedianya kelembagaan yang berfungsi dengan efektif. Artinya, bina kelembagaan tidak cukup dengan pembentukan lembaga-lembaga yang diperlukan, tetapi jauh lebih penting dari pembentukannya, adalah sejauhmana kelembagaan yang telah dibentuk itu berfungsi secara efektif. Ini merupakan tugas pokok pemeritah sebagai salah satu cara menanggulangi kemiskinan melalui pemberdayaan dan menanamkan pemikiran bahwa wisatawan adalah tamu yang dapat membawa uang dan akan menciptakan lapangan pekerjaan, sehingga masyarakat mempunyai kewajiban untuk menghormati dan melayani supaya wisatawan nyaman dan berlama-lama ingin tinggal di tempat wisata. Selain itu pemerintah juga harus melakukan program-program pelatihan untuk masyarakat disekitar lingkungan.

Pemberdayaan masyarakat tidak bersifat selamanya, tetapi sampai target masyarakat mampu untuk belajar bagaimana cara memanfaatkan potensi lingkungan sekitar dan dilepas untuk mandiri setelah mendapatkan pelatihan-pelatihan. Dalam arti luas pemberdayaan masyarakat merupakan proses untuk memfasilitasi dan mendorong masyarakat agar mampu menempatkan diri secara profesional dan menjadi pelaku utama dalam memanfaatkan lingkungan strategisnya untuk mencapai keberlanjutan dalam jangka panjang. ${ }^{23}$

Dalam pembinaan pemberdayaan masyarakat dibidang pariwisata terdapat dua bentuk partisipasi yaitu partisipasi transformasional dan instrumental yang perlu dikembangkan. Hal ini mengingat bahwa pada tahap transformasional, partisipasi masyarakat perlu dibutuhkan dalam membentuk gagasan besar yang mampu menggalang kesadaran untuk perubahan dalam pembangunan kebudayaan dan kepariwisataan. Sedangkan partisipasi instrumental

23 Aprillia Theresia, dkk, Pembangunan Berbasis Masyarakat (Bandung: Alfabeta, 2014), hlm.139. 
merupakan proses pembelajaran dalam masyarakat yang bergerak dibidang pariwisata, dimana dilakukannya sejumlah cara-cara yang mendorong untuk merumuskan permasalahan secara efektif seperti dalam perumusan rencana pengembangan kebudayaan dan pariwisata. ${ }^{24}$

Sebuah agensi relawan Dutch di Belanda, Stichting Nederlandse Vrijwilligers (SNV), mengembangkan pariwisata dengan pemberdayaan masyarakat sebagai berikut:

"Tourism initiatives that are owned by one or more defined communities, or run as joint venture partnerships with the private sector with equitable community participation, as a means of using the natural resources in a sustainable manner to improve their standard of living in an economically viable way.". 25

Makna yang tersirat dari definisi di atas adalah bahwa pengembangan sektor pariwisata yang dimiliki oleh masyarakat tentunya dijalankan dengan sistem kemitraan baik oleh sektor swasta dengan partisipasi masyarakat yang adil, sebagai sarana untuk memanfaatkan sumber daya alam secara berkelanjutan untuk meningkatkan taraf hidup mereka secara ekonomi.

1. Ekonomi Masyarakat

Ekonomi rakyat adalah kegiatan ekonomi yang dilakukan oleh rakyat dengan secara swadaya untuk mengelola sumber daya apa saja ditempat yang dapat dikuasainya dan ditujukan untuk memenuhi kebutuhan dasar beserta keluarganya. ${ }^{26}$ Maka pemerintah harus benar-benar berpihak untuk kesejahteraan rakyat. Kemudian, kebijakan ekonomi yang ditetapkan juga harus menganut pada pemberdayaan ekonomi rakyat agar menjadi perhatian utama.

Langkah pemerintah untuk meningkatkan perekonomian di Indonesia dari berbagai sektor salah satunya adalah sektor pariwisata. Upaya pengerahan sumberdaya masyarakat untuk

\footnotetext{
${ }^{24}$ Http://File.Upi.Edu/Direktori/Fpips/Lainnya/Gumelar_S/Hand_Out_Matkul_Konsep_Resort_A nd_Leisure/Pemberdayaan_Masyarakat_Berbasis_Pariwisata.Pdf (diakses pada 1 November 2017).

${ }^{25}$ Noel B. Salazar, "Community Based Cultural Tourism: Issues, Threats and Opportunities," Journal of Sustainable Tourism, Vol. 20, No. 1, January 2012, 9-22.

26 Cornelis Rintuh dan Miar, Kelembagaan dan Ekonomi Rakyat, (Yogyakarta: BPFEYogyakarta, 2005) hlm. 4.
} 
mengembangkan potensi ekonomi rakyat untuk meningkatkan produktifitas rakyat, baik sumber daya maupun sumber daya alam di sekeliling rakyat dapat ditingkatkan produktifitasnya.

Menurut Foucaults dalam Wearing dan McDonald, bahwa dalam rangka pengembangan masyarakat berbasis pariwisata setidaknya terdapat dua unsur didalamnya, yakni the power or knowledge (kekuatan/pengetahuan) dan govermentality (pemerintahan). ${ }^{27}$ Dalam hal power, Wearing menyarankan bahwa dalam hubungan antara wisatawan dan wakil dari masyarakat dapat menciptakan kekuatan yang erat pada masing-masing struktur sosial dan membangun gagasan. Sedangkan pemerintah adalah pihak yang menaungi sebuah Negara, sehingga dalam hal ini pemerintah harus membuka ruang untuk heterogenitas.

Peran pemerintah daerah baik pemerintah provinsi atau pusat saat ini memegang peranan yang sangat penting untuk mengendalikan perekonomian, terutama pembangunan ekonomi masyarakat kecil di masing-masing daerah, sebagai berikut: ${ }^{28}$

a. Lembaga Kemasyarakatan Desa

Peran lembaga kemasyarakatan desa seperti Lembaga Musyawarah Desa (LMD) dan Lembaga Ketahanan Desa (LKD), Pembinaan Kesejahteraan Keluarga (PKK), Kader Pembangunan Desa (KPD), dan lain-lain, perlu ditingkatkan agar masyarakat desa dapat lebih berpartisipasi aktif dalam pembangunan. Salah satu lembaga ekonomi yang mampu memberikan kesempatan untuk masyarakat desa untuk meningkatkan usaha sesuai dengan kebutuhan dan kesejahteraan mereka adalah Koperasi Unit Desa.

b. Kelembagaan Pasar

Untuk mendorong pembangunan bagi peningkatan pemasaran dan peningkatan kualitas produk. Industri-industri rumah tangga yang berkembang di pedesaan akan merangsang model dan teknologi beralih masuk ke pedesaan. Pemerintah

${ }^{27}$ Stephen Wearing and Matthew McDonald, "The Development of Community-based Tourism: Re-thinking the Relationship Between Tour Operators and Development Agents as Intermediaries in Rural and Isolated Area Communities," Journal of Sustainable Tourism. Vol. 10, No. 3, 2002.

28 Cornelis Rintuh dan Miar, Kelembagaan dan Ekonomi Rakyat, (Yogyakarta: BPFEYogyakarta, 2005) hlm. 58-62. 
berperan penting dalam mengembangkan kelembagaan pasar persaingan sempurna dan pasar yang efesien.

c. Kelembagaan Pendidikan Pelatihan dan Penyuluhan

Dengan meningkatkan pengetahuan masyarakat pedesaan dan makin kuat dunia dalam bidang opertanian, maka terbuka kesempatan yang luas bagi masyarakat. Ini berarti perlu adanya dorongan untuk menciptakan pola kemitraan antara masyarakat dan dunia usaha dengan lembaga-lembaga penelitian yang pada umumnya milik pemerintah, dan sebagian besar terdapat di perguruan tinggi. Upaya paling langsung pemberdayaan ekonomi rakyat di pedesaan ialah memperbaiki kualitas dan kuantitas ketersediaan pelayanan dan penyuluhan.

d. Kelembagaan Permodaalan

Hal ini juga teramat penting untuk penguatan pembangunan perlu upaya penguatan kelembagaan yang dapat mendorong aliran modal ke pedesaan dan mengelolanya untuk mengembangkan potensi .

Adapun teori yang berhubungan dengan kegiatan sistem ekonomi antara lain: ${ }^{29}$

a. Suatu pedoman yang disebut "value judgment" atau "pernilaian subjektif terhadap nilai-nilai" perlu keberhasilan suatu sistem ekonomi dinilai dari kemampuan sistem tersebut memenuhi kebutuhan serta keinginan manusia.

b. Kebutuhan serta keinginan manusia dapat dilihat dari segi komsumsi dan segi produksi.

c. Dari segi konsumsi manusia mempunyai pilihan diantara barang-barang konsumsi dan jasa-jasa yang tersedia..

d. Dari segi produksi, manusia menilai suatu pekerjaan berdasar besarnya upah dan kondisi kerja.

e. Setiap individu menilai kebutuhan dan keinginannya. Dalam hal lingkungan ada orang yang menilai tinggi lingkungan tersebut.

f. Pemerintah dapat menjadi "wakil" pandangan masyarakat karena-individu-individu sering tidak dapat mengemukakan

29 Sukanto Reksohadiprodjo dan Budi Purnomo Brodjonegoro, Ekonomi Lingkungan (Yogyakarta: BPFE-Yogyakarta, 1989) hlm.26-27. 
pernilaiannya terhadap suatu hal. Oleh karena itu, campur tangan pemerintah pada satu lain dan hal dapat dibenarkan.

Dengan demikian koordinasi dalam penyaluran dana maupun memberikan pelatihan itu sangat penting supaya dapat mencapai keberhasilan dan mencegah terjadinya pemborosan sumber-sumber yang terbatas. Karena suatu tugas yang dilaksanakan dengan tugas yang lainnya itu saling berkaitan, sehingga di perlukan kerja sama untuk pencapaiannya. Koordinasi merupakan satu cara untuk pemecahan suatu masalah-masalah penting yang lebih-lebih sesudah terjadinya perang dunia I semakin bertambah sukar tetapi semakin besar pula artinya. ${ }^{30}$

2. Potensi Ekonomi Lokal

Pembangunan adalah upaya perubahan sosial masyarakat suatu bangsa ke arah yang lebih maju dan lebih baik, sesuai dengan pandangan masyarakat itu sendiri. ${ }^{31}$ Jadi adanya pembangunan pada suatu bangsa dimaksudkan agar bisa terjadi suatu perubahan ke arah yang positif tidak hanya pada satu sektor saja tetapi pada semua sektor yang ada sehingga bisa terjadi tercapainya kesejahteraan bagi masyarakat.

Salah satu hal yang bisa mendorong kemajuan pembangunan bangsa adalah potensi ekonomi lokal, potensi ekonomi lokal yang dimaksud disini adalah sumber daya yang ada di desa yang dapat dimanfaatkan untuk meningkatkan ekonomi masyarakat itu sendiri. Dalam mengembangkan potensi ekonomi lokal ini diperlukan strategi yang tepat, agar bisa melihat peluang serta potensi yang dimiliki oleh setiap daerah.

Kondisi dan suasana di desa yang masih alami dan sejuk tentu memiliki potensi untuk dikembangkan dan meningkatkan ekonomi masyarakat lokal. Pada umumnya, banyak orang menerangkan bahwa adanya kemunduran dan perkembangan suatu perekonomian masyarakat bisa dilihat dari sedikit atau banyaknya sumber-sumber alam yang tersedia di desa mereka. ${ }^{32}$

30 Abdul Bashit, Ekonomi Kemasyarakatan: Visi \& Strategi Pemberdayaan Sektor Ekonomi Lemah, (Malang: UIN-MALIKI PRESS, 2012), hlm. 46.

${ }^{31}$ Bintoro Tjokroaminoto, Kebijaksanaan dan Administrasi Pembangunan: Perkembangan Teori dan Penerapan (Jakarta: Pustaka LP3ES, 1998), hlm. 4.

32 Irawan, Suparmoko, Ekonomi Pembangunan: Edisi Keenam, (Yogyakarta: BPFE-Yogyakarta, 1997), hlm. 159 
Pembangunan yang didukung dengan prioritas potensi ekonomi lokal yang unggul di desa, akan membantu meningkatkan pertumbuhan ekonomi. Potensi ekonomi lokal yang unggul adalah suatu sektor perekonomian atau usaha yang produktif untuk dikembangkan sebagai potensi pembangunan dan dapat menjadi basis perekonomian suatu daerah. ${ }^{33}$ Potensi ekonomi disetiap daerah tentu berbeda dan tidak sama tergantung pada lokasi dan budaya masing-masing daerah.

Ada banyak potensi lokal yang bisa dimanfaatkan oleh masyarakat di Indonesia, seperti potensi yang ada di daratan adalah potensi pertanian, peternakan, perkebunan, petambangan, dan pemukiman. Sedangkan potensi perairan bisa dimanfaatkan untuk perikanan, transportasi, dan rekreasi. Sedangkan potensi budaya yang bisa dimanfaatkan oleh masyarakat Indonesia adalah kesenian daerah yang memiliki ke-khasan sendiri di setiap daerah.

Setiap potensi tersebut dapat dimanfaatkan oleh masyarakat sekitar, namun sayangnya ada banyak masyarakat yang tidak menyadari bahwa daerah mereka memiliki potensi ekonomi lokal yang bisa dikembangkan. Oleh karena itu, pemberdayaan pada masyarakat sangat penting dilakukan. Kegiatan pemberdayaan masyarakat ini difokuskan pada upaya untuk menolong orangorang lemah yang memiliki minat untuk bekerjasama dalam kelompok, mengidentifikasi kebutuhan dan melakukan kegiatan secara kelompok untuk memenuhi kebutuhan mereka. ${ }^{34}$

Dalam pemberdayaan masyarakat dibutuhkan keaktifan dan ke-kreatifan masyarakat agar dapat terealisasi pembangunan yang berkelanjutan dengan memanfaatkan potensi ekonomi didaerah mereka. Setiap potensi yang ada di daerah, bisa mereka manfaatkan ke sektor pariwisata, tergantung dari bagaimana mereka mengelola dan mengembangkan potensi yang ada di daerah mereka.

Dilihat dari berbagai aspek, seperti aspek budaya, kekayaan alam, dan kebhinekaan yang dimiliki, Indonesia memiliki modal ekonomi kreatif yang potensial sebagai berikut: ${ }^{35}$

\footnotetext{
${ }^{33}$ Samuel Johanis Atama, Analisis Potensi Ekonomi Lokal Untuk Pengembangan dan Penguatan Daya Saing Daerah di Kabupaten Alor Tahun 2009-2013, Jurnal, (NTT: Alor, 2014), hlm. 3

${ }^{34}$ Zubaedi, Pengembangan Masyarakat: Wacana dan Praktik, (Jakarta: Kencana, 2013), hlm. 4

35 Suryana, Ekonomi Kreatif, Ekononomi Baru: Mengubah Ide dan Menciptakan Peluang, (Jakarta: Salemba Empat, 2013), hlm. 49-50.
} 
a. Modal seni, budaya, dan warisan budaya. Keanekaragaman budaya yang dimiliki oleh setiap daerah di Indonesia dengan masing-masing ciri khasnya bisa dikembangkan secara komersial untuk meningkatkan ekonomi masyarakat lokal. Salah satu caranya adalah dengan menggelar pertunjukkan seni budaya di daerah mereka, sehingga akan banyak menarik wisatawan datang untuk melihat pertunjukkan.

b. Modal sumber daya dan kekayaan alam. Indonesia dianugrahi kekayaan alam yang sangat melimpah dan beranekaragam. Keadaan tanah yang subur, laut yang luas merupakan potensi yang dapat dimanfaatkan untuk meningkatkan ekonomi masyarakat. Ada banyak jenis usaha yang bisa dimanfaatkan untuk meningkatkan pendapatan seperti usaha kreatif hasil pertambangan, pertanian, perkebunan, peternakan, perikanan, dan lain sebagainya. Selain memanfaatkan potensi yang ada dalam bentuk barang atau benda, masyarakat juga bisa menjadikan lahan pertambangan, pertanian, perkebunan, dan peternakan sebagai eduwisata dan ekowisata. Eduwisata atau wisata pendidikan adalah wisata yang memiliki tujuan untuk menambah ilmu atau pendidikan bagi wisatawan yang berkunjung, sedangkan ekowisata atau wisata berwawasan lingkungan adalah kegiatan wisata yang mengutamakan aspek pemberdayaan sosial, budaya, dan ekonomi masyarakat lokal.

c. Modal kebinekaan suku bangsa, budaya, bahasa, dan agama. Suku bangsa, budaya, dan bahasa merupakan modal ekonomi kreatif yang dapat dikembangkan menjadi kekayaan bangsa. Lagu-lagu daerah, bahasa daerah, kesenian daerah, makanan daerah, dan rumah adat daerah merupakan poteni ekonomi lokal yang bisa dikembangkan secara komerisal untuk meningkatkan kesejahteraan masyarakat lokal.

Ketiga modal tersebut merupakan potensi ekonomi yang dapat dikelola, dan dikembangkan secara komersial. Untuk mengelola dan mengembangkan ketiga modal tersebut, terlebih dahulu perlu dikembangkan modal insani atau sumber daya manusia. Untuk mengembangkan atau memberdayakan sumber daya manusia tersebut dilakukan melalui investasi pendidikan, pelatihan, dan juga pembinaan untuk mendorong sumber daya manusia yang lebih berpengetahuan dan berwawasan luas. 
Melalui pendidikan, pelatihan, dan pembinaan yang dilakukan, masyarakat akan diberikan pengetahuan-pengetahuan seputar potensi yang ada di daerah mereka dan bagaimana cara mereka memanfaatkan potensi tersebut. Dari pelatihan dan pembinaan yang dilakukan tersebut, diharapkan agar masyarakat bisa mengelola serta mengembangkan potensi yang sudah tersedia di desa mereka.

Dari ide dan gagasan yang dimiliki oleh masyarakat yang telah dilatih dan dibina itulah peluang akan muncul, sehingga bisa menciptakan iklim bisnis, membuka lapangan pekerjaan untuk masyarakat sekitar, menumbuhkan inovasi serta kreativitas, serta ikut berkontribusi terhadap kesejahteraan masyarakat. Secara non ekonomi, pemberdayaan masyarakat dengan memanfaatkan potensi ekonomi lokal juga berperan dalam membangun budaya, mempertahankan budaya dan sekaligus mengenalkan daerah serta adat istiadat di daerah mereka.

\section{Potensi Wisata dalam Pemberdayaan Masyarakat}

Pariwisata adalah salah satu dari industri baru yang mampu meningkatkan pertumbuhan ekonomi dengan cepat dalam hal kesempatan kerja, pendapatan, taraf hidup dan dalam hal mengaktifkan sektor produksi lain didalam negara penerima wisatawan. ${ }^{36}$ Menurut Rozemeijer dalam Salazar, tedapat empat dimensi yang penting dalam pengembangan wisata keberlanjutan, yaitu:

a. CBT should be economically viable: the revenue should exceed the costs;

b. CBT should be ecologically sustainable: the environment should not decrease in value;

c. There should be an equitable distribution of costs and benefits among all participants in the activity; and

d. Institutional consolidation should be ensured: a transparent organisation, recognized by all stakeholders, should be established to represent the interests of all community members and to reflect true ownership. ${ }^{37}$

${ }^{36}$ I Gusti Bagus Rai Utama, Pengantar Industri Pariwisata: Tantangan dan Peluang Bisnis Kreatif, (Yogyakarta: Deeplublish, 2012) hlm. 20.

${ }^{37}$ Noel B. Salazar, "Community Based Cultural Tourism: Issues, Threats and Opportunities," Journal of Sustainable Tourism, Vol. 20, No. 1, January 2012, 9-22. 
Keempat dimensi ini apabila terlaksana dengan baik, maka pengembangan sektor pariwisata dengan system pemberdayaan masyarakat melalui dikatakan berhasil.

Menurut Tosun, partisipasi masyarakat dalam pembangunan dapat membuka jalan untuk penerapan prinsip-prinsip pengembangan pariwisata berkelanjutan dan menciptakan kesempatan yang lebih baik bagi masyarakat lokal untuk mendapatkan manfaat yang lebih banyak dari perkembangan pariwisata yang terjadi di daerah mereka. ${ }^{38}$ Sebagaimana ungkapan Murphree bahwa manfaat akan diperoleh sebanding dengan usaha yang dilakukan. ${ }^{39}$ Hal ini akan berbanding terbalik jika masyarakat tidak merasa memiliki dan ikut berpartisipasi secara aktif. Sehingga kesuksesan bergantung pada masyarakat selain pemerintah yang juga sebaagai penggerka aktif. ${ }^{40}$

Indonesia memiliki sejumlah potensi wisata yang bisa dimanfaatkan sebagai sarana pemberdayaan masyarakat. Di antaranya adalah beberapa wisata berikut ini: ${ }^{41}$

1. Wisata Budaya

Wisata budaya merupakan wisata yang dilakukan untuk mengetahui keadaan masyarakat di suatu wilayah, dan mengetahui kebiasaan atau adat istiadat di daerah yang dikunjungi. Di Indonesia ada beberapa wisata budaya yang telah banyak dikenal wisatawan, contohnya adalah candi Borobudur dan Candi Prambanan. Dalam wisata budaya, tentu harus ada peran dari masyarakat sekitar, karena tujuan dari wisata budaya itu adalah untuk mengetahui kebiasaan serta adat istiadat di daerah mereka.

2. Wisata Maritim atau Bahari

Wisata maritim atau wisata bahari adalah potensi wisata yang banyak dikaitkan dengan kegiatan olahraga di air seperti danau, pantai, teluk, atau laut. Kegiatan olahraga yang bisa dilakukan adalah memancing, berlayar, dan berselancar, selain untuk kegiatan

38 C. Tosun, Limits to Community Participation in the Tourism Development Process in Developing Countries. Tourism Management, 21(6), 2000. 613-633.

39 M. W. Murphree, Congruent objectives, competing interests and strategic compromise: Concepts and processes in the evolution of Zimbabwe's CAMPFIRE programme. Manchester: Manchester Institute for Development Policy and Management. 1999.

${ }^{40}$ Lesego Senyana Stone dan Tibabo Moren Stone, Community-based tourism enterprises: challenges and prospects for community participation; Khama Rhino Sanctuary Trust, Botswana, Journal of Sustainable Tourism , Vol. 19, No. 1, January 2011, 97-114.

${ }^{41}$ I Gusti Bagus Rai Utama, Pemasaran Pariwisata, (Yogyakarta: CV Andi Offset, 2017), hlm. 145- 162 
olahraga wisata maritim juga bisa untuk me-relax kan mata dengan pemandangan-pemandangan yang sejuk dan indah. Di Indonesia ada banyak potensi wisata maritim ini seperti misalnya danau toba, dan laut-laut yang ada di Pulau Bali.

3. Wisata Cagar Alam

Wisata cagar alam adalah suatu perjalanan yang ke daerah taman lindung, hutan daerah dan pegunungan atau tempat-tempat yang kelestariannya dilindungi oleh undang-undang. Dalam perjalanan wisata cagar alam ini biasanya wisatawan akan disajikan dengan pemandangan tumbuhan yang hijau dan beraneka ragam satwa serta pepohonan kembang yang beraneka ragam yang memang dilindungi pemerintah dan masyarakat.

4. Wisata Agro

Filosofi wisata agro adalah meningkatkan pendapatan kaum tani dan meningkatkan kualitas alam pedesaan menjadi hunian yang benar-benar dapat diharapkan sebagai hunian yang berkualitas, memberi kesempatan masyarakat untuk belajar kehidupan pertanian yang menguntungkan dan ekosistemnya.

Dengan adanya pembangunan pariwisata yang terarah diharapkan menjadi peluang bagi masyarakat khususnya petani setempat untuk meningkatkan kesejahteraannya. Agrowisata juga dapat menjadikan peluang kerja bagi para pemuda pemudi sehingga mereka tidak perlu pergi ke kota untuk bekerja.

Sementara agrowisata bagi wisatawan adalah mendidik wisatawan untuk memahami kehidupan nyata tentang pertanian dan memberikan pemahaman kepada wisatawan bahwa kehidupan bertani adalah suatu pekerjaan yang sangat mulia, karena kehidupan manusia lainnya sangat tergantung pada pertanian. Wisatawan juga dapat menikmati alam yang sejuk dan indah yang bebas dari polusi udara seperti di kota, serta dapat membeli hasil-hasil pertanian yang masih segar bahkan organik.

Agrowisata adalah pemanfaatan alam sebagai atraksi wisata. Atraksi wisata ini dapat berupa arum jeram, cruising, taman burung, taman gajah, taman reptil, taman kupu-kupu, taman anggrek, air terjun, pegunungan dan sumberdaya fisik lainnya.

5. Wisata Buru

Wisata buru banyak dilakukan di negara-negara yang memang memiliki hutan atau daerah berburu yang dibenarkan oleh 
pemerintah negara yang bersangkutan seperti berbagai negara di Afrika. Di Indonesia pemerintah membuka wisata berburu untuk daerah Baluran di Jawa Timur dimana wisatawan boleh menembak banteng atau babi hutan.

6. Wisata Ziarah

Jenis wisata ini banyak dikaitkan dengan agama, sejarah, adat istiadat dan kepercayaan umat atau kelompok dalam masyarakat. Wisata ziarah banyak dilakukan oleh perorangan atau rombongan ke tempat-tempat suci seperti makam-makam orang besar atau pemimpin yang diagungkan; ke bukit atau gunung yang dianggap keramat; tempat pemakaman tokoh atau pemimpin sebagai manusia ajaib penuh legenda. Biasanya hal ini dapat dihubungkan dengan niat wisatawan untuk memperoleh restu, kekuatan batin, keteguhan iman dan kekayaan yang melimpah.

Dari potensi-potensi wisata yang telah disebutkan di atas, semuanya dapat dimanfaatkan oleh pemerintah sebagai sarana untuk pemberdayaan masyarakat. Ada banyak peluang yang bisa dimanfaatkan oleh masyarakat dari potensi-potensi tersebut untuk meningkatkan kesejahteraan. Secara praktis, upaya pengerahan sumber daya untuk mengembangkan potensi ekonomi rakyat ini akan meningkatkan produktivitas rakyat, sehingga baik sumber daya manusia, maupun sumberdaya alam disekitar keberadaan rakyat dapat ditingkatkan produktivitasnya. Dengan demikian, rakyat dan lingkungannya mampu secara partisipatif menghasilkan dan menumbuhkan nilai tambah ekonomis.

Rakyat miskin atau yang berada pada posisi belum termanfaatkan secara penuh potensinya akan meningkat bukan hanya ekonominya, tetapi juga harkat, martabat, rasa percaya diri, dan harga dirinya. Dengan demikian, dapatlah diartikan bahwa pemberdayaan tidak saja menumbuhkan dan mengembangkan nlai ekonomis, tetapi juga nilai tambah sosial, dan nilai tambah budaya. Jadi, partisipasi rakyat meningkatkan emansipasi rakyat. ${ }^{42}$

\section{Penutup}

Pariwisata di Indonesia telah mendunia karena potensi pariwisatanya yang beraneka ragam dan memiliki keindahan alam

42 Ginandjar Kartasasmita, Pembangunan Untuk Rakyat: Memadukan Pertumbuhan dan Pemerataan, (Jakarta: PT. Pustaka Cidesindo, 1996), hlm. 142 
yang luas. Namun hal tersebut tidak membuat masyarakat sekitar tempat wisata menikmati banyak manfaat dari berkembangnya aspek wisata di daerahnya karena keterbatasan masyarakat tentang pemahaman potensi wisata yang dimiliki di daerahnya, sehingga pemerintah mempunyai tugas dan tanggung jawab untuk memberdayakan masyakarat agar masyakat mengetahui bahwa daerah mereka berpotensi dan mengetahui bagaimana cara memanfaatkan potensi wisata tersebut.

Konsep pemberdayaan masyarakat berbasis pariwisata merupakan suatu konsep yang menegaskan bahwa posisi masyarakat bukan lagi hanya sebagai objek, tetapi juga subjek. Pada posisi objek, maksudnya adalah masyarakat masih perlu diberikan bimbingan atau arahan agar pengelolaan bisa terus berkembang dan bisa mencapai tujuan, sedangkan pada posisi subjek yaitu masyarakat adalah penentu dalam pembangunan itu sendiri, masyarakat adalah pelaku yang sangat penting dalam menentukan keberhasilan dari pembangunan yang sedang dilakukan.

Pariwisata adalah salah satu dari industri baru yang mampu meningkatkan pertumbuhan ekonomi dengan cepat dalam hal kesempatan kerja, pendapatan, taraf hidup dan dalam hal mengaktifkan sektor produksi lain di dalam negara penerima wisatawan. Oleh karena itu, pembangunan pariwisata berbasis kearifan lokal secara tidak langsung juga berdampak pada masyarakat agar ikut berperan aktif dalam mengembangkan potensi-potensi yang ada di daerah mereka sehingga bisa meningkatkan kesejahteraan hidup mereka. 


\section{Daftar Pustaka}

Adisasmita, Rahardjo. 2005. Dasar-Dasar Ekonomi Wilayah. Yogyakarta: Graha Ilmu.

Bashit, Abdul. 2012. Ekonomi Kemasyarakatan: Visi \& Strategi Pemberdayaan Sektor Ekonomi Lemah. Malang: UIN-MALIKI PRESS

Kartasasmita, Ginandjar. 1996. Pembangunan Untuk Rakyat: Memadukan Pertumbuhan dan Pemerataan. Jakarta: PT. Pustaka Cidesindo.

Mardikanto, Totok. 2012. Pemberdayaan Masyarakat: Dalam Perspektif Kebijakan Publik. Bandung: Penerbit Alfabeta.

Notoatmodjo, Soekidjo. 1998. Pengembangan Sumber Daya Manusia. Jakarta: PT Rineka Cipta.

Nugroho, Iwan. 2011. Ekowisata dan Pembangunan Berkelanjutan. Yogyakarta: Pustaka Pelajar.

Reksohadiprodjo, Sukanto \& Purnomo, Brodjonegoro, Budi. 1989. Ekonomi Lingkungan. Yogyakarta: BPFE-Yogyakarta.

Rintuh, Cornelis, \& Miar. 2005. Kelembagaan dan Ekonomi Rakyat. Yogyakarta: BPFE-Yogyakarta.

Shahab, Kurnadi. 2013. Sosiologi Pedesaan. Yogyakarta: Ar-Ruzz Media.

Sjafrizal. 2016. Perencanaan Pembangunan Daerah Dalam Era Otonomi. Depok: RajaGrafindo Persada.

Suhartini, Rr, dkk. 2005. Model-Model Pemberdayaan Masyarakat. Yogyakarta: PT LKiS Pelangi Aksara.

Suparmoko, Irawan. 1997. Ekonomi Pembangunan: Edisi Keenam. Yogyakarta: BPFE-Yogyakarta.

Suryana. 2013. Ekonomi Kreatif, Ekononomi Baru: Mengubah Ide dan Menciptakan Peluang. Jakarta: Salemba Empat.

Theresia, Aprillia, dkk. 2014. Pembangunan Berbasis Masyarakat. Bandung: Alfabeta.

Tjokroaminoto, Bintoro. 1998. Kebijaksanaan dan Administrasi Pembangunan: Perkembangan Teori dan Penerapan. Jakarta: Pustaka LP3ES.

Usman, Sunyoto. 2012. Pembangunan dan Pemberdayaan Masyarakat. Yogyakarta: Pustaka Pelajar.

Utama, I Gusti Bagus Rai. 2012. Pengantar Industri Pariwisata: Tantangan dan Peluang Bisnis Kreatif. Yogyakarta: Deeplublish. 
Utama, I Gusti Bagus Rai. 2017. Pemasaran Pariwisata. Yogyakarta: CV Andi Offset.

Zubaedi. 2013. Pengembangan Masyarakat: Wacana dan Praktik. Jakarta: Kencana.

Nanih Machendrawaty dan Agus Ahmad Safe'i, 2001. Pengembangan Masyarakat Islam, (Bandung: Rosdakarya.

\section{Penelitian:}

Johanis Atama, Samuel. 2014. "Analisis Potensi Ekonomi Lokal Untuk Pengembangan dan Penguatan Daya Saing Daerah di Kabupaten Alor Tahun 2009-2013" Jurnal. NTT: Alor.

Rizki F, Anggiar, dkk. 2016. "Peran Serta Masyarakat Desa Dalam Inisiasi Pengembangan Wisata Alam Desa Wringinanom Keamatan Poncokusumo Kabupaten Malang" Jurnal. Malang: Unversitas Brawijaya.

Susyanti, Dewi Winarni. 2014. "Potensi Desa Melalui Pariwisata Pedesaan" Jurnal. Jakarta: Politeknik Negeri Jakarta.

Stephen Wearing and Matthew McDonald, "The Development of Community-based Tourism: Re-thinking the Relationship Between Tour Operators and Development Agents as Intermediaries in Rural and Isolated Area Communities," Journal of Sustainable Tourism. Vol. 10, No. 3, 2002.

Lesego Senyana Stone dan Tibabo Moren Stone, Community-based tourism enterprises: challenges and prospects for community participation; Khama Rhino Sanctuary Trust, Botswana, Journal of Sustainable Tourism, Vol. 19, No. 1, January 2011, 97-114.

Murphree, M.W. (1999). Congruent objectives, competing interests and strategic compromise: Concepts and processes in the evolution of Zimbabwe's CAMPFIRE programme. Manchester: Manchester Institute for Development Policy and Management

C. Tosun, Limits to Community Participation in the Tourism Development Process in Developing Countries. Tourism Management, 21(6), 2000. 613-633.

Noel B. Salazar, "Community Based Cultural Tourism: Issues, Threats and Opportunities," Journal of Sustainable Tourism, Vol. 20, No. 1, January 2012, 9-22. 


\section{Website:}

http://file.upi.edu/direktori/fpips/lainnya/gumelar_s/hand_out_matkul_kon sep_resort_and_leisure/pemberdayaan_masyarakat_berbasis_pariwi sata.pdf

http://googleweblight.com/

http://setkab.go.id/bps-per-september-2016-jumlah-penduduk-miskinindonesia-bekurang-025-juta/ 